\title{
Relationship between Perinatal Period Problems and Developmental Delay in Children Aged 4-24 Months
}

\author{
Masoumeh Kaviani ${ }^{1}$, Zhaleh Ranjbaran², Roksana Janghorban ${ }^{3}$ \\ ${ }^{1}$ Department of Midwifery, School of Nursing and Midwifery, \\ Community-based Psychiatric Care Research Center, Shiraz University of Medical Sciences, Shiraz, Iran \\ ${ }^{2} \mathrm{MSc}$ student, Student Research Committee, Department of Midwifery, \\ School of Nursing and Midwifery, Shiraz University of Medical Sciences, Shiraz, Iran \\ ${ }^{3}$ Department of Midwifery, School of Nursing and Midwifery, Maternal-Fetal Medicine Research Center, \\ Shiraz University of Medical Sciences, Shiraz, Iran
}

SUMMARY

Normal development is one of the reliable criteria for the assessment of children's health status. Perinatal events affect the future development of children. Nevertheless, there are different views on the impact of events in the perinatal period on child development. The aim of this study was to determine the relationship between perinatal period and developmental delay in 4-24-month-old children.

Three hundred and thirty children aged 4-24 months who were referred to Imam Reza Clinical Development Center and Shiraz Health Centers were enrolled. Information about perinatal events was collected by a researcher-made questionnaire containing demographic and reproductive information related to pregnancy, delivery and neonatal period. The developmental status of children was evaluated by age and stage questionnaire. Data were analyzed using Chi-square, Mann-Whitney and logistic regression by SPSS version 14 .

Sex $(P=0.025)$, maternal medical problems $(P=0.011)$, fetal distress $(P=0.022)$, history of hospitalization in the neonatal intensive care unit $(P<0.001)$, severe neonatal jaundice $(P=0.005)$ and small for gestational age $(P=0.012)$ after controlling the confounding of other factors had a significant effect on developmental delay.

The results of this study showed that being male, having maternal medical problems, fetal distress, the history of hospitalization in the neonatal intensive care unit, severe neonatal jaundice and small for gestational age can predict developmental delay. Special attention to screening of children who are at risk of developmental delay due to perinatal conditions can be effective in early diagnosis of developmental delay.

Key words: children, developmental delay, infant, perinatal period 


\section{INTRODUCTION}

Creating a framework for healthy development in the early years of life is a prerequisite for individual well-being, economic productivity, and social balance throughout the world (1). One of the goals of pediatric medicine is helping children to achieve their potential for development (2). The development process is not determined solely by genetic or individual factors, nor is it a complete product of the acquired environmental effects. In fact, the pattern of individual development per person over a lifetime, on the one hand, influences the risk factors that increase the probability of a negative outcome and, on the other hand, there are protective factors that increase the likelihood of a positive outcome. Identification of the risk factors is important for establishing policies for the prevention of developmental delay. Studies aimed at identifying the risk factors for developmental delay play an important role in creating intervention strategies (3). Detecting children at risk of developmental delay and initiating interventions before or after the occurrence of a problem can prevent many of the consequences of developmental delays. Problems that occur during labor, delivery, and postnatally can be the risk factors for developmental delays. In fact, many developmental delays can return to the perinatal period (4), so identifying the risk factors for developmental delay is essential in this period.

Several studies have been conducted on perinatal risk factors affecting the developmental delay of children, but there has been no consensus on this issue. In most of these studies, the impact of neonatal complications on developmental delay has been studied and most of these studies have been performed on children with preterm birth (5-8). In the existing studies, less attention has been paid on the effects of factors in the period of pregnancy and childbirth, and in most studies only one complication during pregnancy or childbirth, such as preeclampsia, has been addressed (9). Most of these studies have also been conducted in developed countries $(5-7,9,10)$, and only a small number of studies have been conducted in developing countries (11).

A study that examined a number of perinatal factors' influences on developmental delays and examined the impact of these factors together was not found, so the aim of this study was to investigate the relationship between the complications in the perinatal period and developmental delay in 4-24-monthold children.

\section{PATIENTS AND METHODS}

\section{Subjects}

This case-control study was conducted on 330 children aged $4-24$ months who referred to health centers and development center of Imam Reza clinic in Shiraz, Iran in 2017. These children were checked for entry to the study if they had parents' consent, no genetic and metabolic disease, and major congenital anomalies, and had a health record. Children who scored their points based on the completion of the Age Stage Questionnaire (ASQ) in at least one of the developmental areas below the cut-off point of two standard deviations below the average were placed in the case group, and children whose grades on the basis of ASQ completion in all developmental areas were equal or above the cut-off point of one standard deviation below the average were assigned to the control group. Children with inadequate health records and unclear gestational age at birth were excluded.

Sampling in the control group was performed among 4 - 24 months old children who were referred to Shiraz health centers for doing health care and vaccination. To avoid bias, sampling for the control group was not done at development center of Imam Reza clinic. In the control group, health centers in different regions of Shiraz were selected as clusters and then, according to the population of children under two years old, a quota was allocated to each cluster. Sampling days in the centers were also selected randomly.

The case group sampling was done at Imam Reza Development Center of Shiraz, which is a referral center for the diagnosis and treatment of child developmental delays. In this center, a team of neurologist, pediatricians, psychologists, occupational therapists, speech therapists, and experienced experts will examine the development of 4 to 60month-old children who had been referred there from other centers or the center itself.

\section{Study protocol}

In both groups, after description of the goals of the study to the parents and ensuring the confidentiality of the information, written informed consent of the parents was taken to allow the assessment of the mother's and the child's medical records and the child's entry into the study. First, a 
researcher-made questionnaire was used to collect information by interviewing parents and using the maternal and child health records.

This questionnaire consists of four sections including: demographic and reproductive information (birth date and child sex, number of children, birth order, history and number of abortion, history of infertility, and the status of the use of assisted reproductive technology in the birth of a child), information about pregnancy (placenta previa, diabetes, maternal medical illness, high blood pressure, vaginal bleeding during the first trimester of pregnancy, anemia, hypothyroidism and drug consumption), information about delivery (mode of delivery, type of cesarean, preterm delivery, fetal distress) and neonatal information (prematurity, small for gestational age (SGA), birth weight, multiple births, and history and duration of admission in neonatal intensive care unit (NICU), history of severe jaundice in neonatal period and history of neonatal seizure).

Age Stage Questionnaire (ASQ), a parentreport questionnaire, was chosen for the assessment of children's developmental status because it has been proven to be a valid and/or reliable screening test, even in its translated and culturally adapted versions in different populations of children $(12,13)$.
The reliability of ASQ in Iran, determined by Cronbach's alpha ranged from 0.76 to 0.86 and the inter-rater reliability was 0.93 . The validity determined by factor analysis was satisfactory (14).

\section{Statistical analysis}

To test the relationship between two qualitative factors, the Chi-square test, or equivalent, the Fisher's exact test was used. To compare the mean of a quantitative factor between two independent groups, the Mann-Whitney test was used. Normality of the data was evaluated by the Kolmogorov-Smirnov test and the equality test was performed in the two groups with the Leven's test. Binary logistic regression model was used to investigate the effect of relevant factors on developmental status of children (developmental delay and normal development). Data analysis was performed using the statistical software (SPSS version 14.0, SPSS Inc., Chicago, IL, USA) at a significant level of 0.05 .

\section{RESULTS}

In this study, 330 children including 165 children aged 4 - 24 months with abnormal ASQ score

Table 1: Demographic and reproductive information in case and control groups

\begin{tabular}{|c|c|c|c|c|}
\hline Variables & Case & Control & OR $(95 \% \mathrm{CI})^{* * *}$ & P value \\
\hline Number of children (Mean \pm SD) & $1.77 \pm 0.89$ & $2.3 \pm 1.57$ & $0.69(0.57-0.86)$ & $0.004^{*}$ \\
\hline Number of abortions (Mean \pm SD) & $0.37 \pm 0.78$ & $0.33 \pm 0.68$ & $1.08(0.79-1.47)$ & $0.692^{*}$ \\
\hline \multicolumn{4}{|l|}{ Child - Sex } & \multirow{3}{*}{$0.018^{* *}$} \\
\hline Male $\mathrm{N}(\%)$ & $99(32)$ & $79(25.6)$ & $1.73(1.1-2.73)$ & \\
\hline Female $\mathrm{N}(\%)$ & $55(17.8)$ & $76(24.6)$ & 1.00 Reference & \\
\hline \multicolumn{4}{|l|}{ History of abortion } & \multirow{3}{*}{$0.48^{* *}$} \\
\hline Yes N(\%) & $39(12.6)$ & $34(11)$ & $1.21(0.71-2.04)$ & \\
\hline No N $(\%)$ & $115(37.2)$ & $121(39.2)$ & 1.00 Reference & \\
\hline \multicolumn{4}{|l|}{ Assisted reproduction therapy } & \multirow{3}{*}{$0.173^{* *}$} \\
\hline Yes N(\%) & $6(1.9)$ & $2(0.6)$ & $3.10(0.62-15.61)$ & \\
\hline No N(\%) & $148(47.9)$ & $153(49.5)$ & 1.00 Reference & \\
\hline \multicolumn{4}{|l|}{ Infertility history } & \multirow{3}{*}{$0.094^{* *}$} \\
\hline Yes $\mathrm{N}(\%)$ & $13(4.3)$ & $6(1.9)$ & $2.29(0.85-6.19)$ & \\
\hline No N(\%) & $141(45.6)$ & $149(48.2)$ & 1.00 Reference & \\
\hline
\end{tabular}


Table 2: Univariate analysis used for examining the relationship between pregnancy complications and developmental delay

\begin{tabular}{|c|c|c|c|c|}
\hline Variables & $\begin{array}{l}\text { Case } \\
\mathrm{N}(\%) \\
\end{array}$ & $\begin{array}{c}\text { Control } \\
\mathrm{N}(\%)\end{array}$ & OR $(95 \% \mathrm{CI})$ & $\begin{array}{c}\mathbf{P} \\
\text { value }^{*}\end{array}$ \\
\hline \multicolumn{5}{|c|}{ Insulin-dependent diabetes } \\
\hline Yes & $3(1)$ & $5(1.6)$ & $0.6(0.39-7.15)$ & \multirow[t]{2}{*}{0.484} \\
\hline No & $151(48.9)$ & $150(48.5)$ & 1.00 Reference & \\
\hline \multicolumn{4}{|c|}{ Maternal hypothyroidism in pregnancy } & \multirow{3}{*}{0.336} \\
\hline Yes & $18(5.8)$ & $13(4.2)$ & $1.45(0.68-3.06)$ & \\
\hline No & $136(44.0)$ & $142(46.0)$ & 1.00 Reference & \\
\hline \multicolumn{4}{|c|}{ Placenta previa } & \multirow{3}{*}{0.090} \\
\hline Yes & $9(2.9)$ & $3(1.0)$ & $3.15(0.84-11.85)$ & \\
\hline No & $145(46.9)$ & $152(49.2)$ & 1.00 Reference & \\
\hline \multicolumn{4}{|c|}{ **Maternal medical problems } & \multirow{3}{*}{0.023} \\
\hline Yes & $11(3.6)$ & $2(0.6)$ & $5.88(1.3-27.00)$ & \\
\hline No & $143(46.3)$ & $153(49.5)$ & 1.00 Reference & \\
\hline \multicolumn{4}{|c|}{ *** High blood pressure } & \multirow{3}{*}{0.423} \\
\hline Yes & $9(2.9)$ & $6(1.9)$ & $1.54(0.53-4.4)$ & \\
\hline No & $145(46.9)$ & $149(48.2)$ & 1.00 Reference & \\
\hline \multicolumn{4}{|c|}{ Drug consumption in pregnancy } & \multirow{3}{*}{$<0.001$} \\
\hline Yes & $65(21.0)$ & $33(10.7)$ & $2.70(1.64-4.45)$ & \\
\hline No & $89(28.8)$ & $122(39.5)$ & 1.00 Reference & \\
\hline \multicolumn{4}{|c|}{$* * * *$ Maternal anemia in pregnancy } & \multirow{3}{*}{0.992} \\
\hline Yes & $5(1.6)$ & $5(1.6)$ & $1.0(0.29-3.5)$ & \\
\hline No & $149(48.2)$ & $150(48.5)$ & 1. 00 Reference & \\
\hline \multicolumn{4}{|c|}{ Vaginal bleeding in first trimester } & \multirow{3}{*}{$<0.001$} \\
\hline Yes & $20(6.5)$ & $1(0.3)$ & $22.99(3.04-173.5)$ & \\
\hline No & $134(43.4)$ & $154(49.8)$ & 1.00 Reference & \\
\hline
\end{tabular}

Table 3: Univariate analysis showing the relationship between delivery data and developmental delay

\begin{tabular}{|c|c|c|c|c|}
\hline Variables & $\begin{array}{l}\text { Case } \\
\mathrm{N}(\%)\end{array}$ & $\begin{array}{c}\text { Control } \\
\mathrm{N}(\%)\end{array}$ & OR(95\% CI) & $P$ value \\
\hline \multicolumn{4}{|c|}{ Mode of delivery } & \multirow{3}{*}{0.075} \\
\hline C-section & $94(30.4)$ & $79(25.6)$ & $1.51(0.96-2.37)$ & \\
\hline Vaginal & $60(19.4)$ & $76(24.6)$ & 1.00 Reference & \\
\hline \multicolumn{4}{|c|}{ Type of c-section } & \multirow{3}{*}{0.001} \\
\hline Emergency & $51(29.5)$ & $23(13.3)$ & $2.88(1.53-5.54)$ & \\
\hline Elective & $43(24.9)$ & $56(32.4)$ & 1.00 Reference & \\
\hline \multicolumn{4}{|l|}{ Preterm birth } & \multirow{3}{*}{0.001} \\
\hline Yes & $42(13.6)$ & $18(5.8)$ & $2.85(1.56-5.23)$ & \\
\hline $\mathrm{No}$ & $112(36.2)$ & $137(44.3)$ & 1.00 Reference & \\
\hline \multicolumn{4}{|l|}{ Fetal distress } & \multirow{3}{*}{0.003} \\
\hline Yes & $17(5.5)$ & $4(1.3)$ & 4.68 (1.55-14.46) & \\
\hline $\mathrm{No}$ & $137(44.3)$ & $151(48.9)$ & 1.00 Reference & \\
\hline
\end{tabular}


Table 4: Univariate analysis presenting the correlation between neonatal complications and developmental delay

\begin{tabular}{|c|c|c|c|c|}
\hline Variables & $\begin{array}{l}\text { Case } \\
\mathrm{N}(\%) \\
\end{array}$ & $\begin{array}{c}\text { Control } \\
\mathrm{N}(\%)\end{array}$ & OR $(95 \%$ CI) & P value \\
\hline \multicolumn{4}{|l|}{ SGA $^{*}$} & \multirow{3}{*}{$<0.001$} \\
\hline Yes & $20(6.5)$ & $2(0.6)$ & $11.42(2.62-49.7)$ & \\
\hline $\mathrm{No}$ & $134(43.4)$ & $153(49.5)$ & 1.00 Reference & \\
\hline \multicolumn{4}{|l|}{$\mathrm{BW}(\mathrm{gr})^{* *}$} & \multirow{3}{*}{$<0.001$} \\
\hline$<2500$ & $56(18.1)$ & $13(4.2)$ & $6.24(3.24-12.02)$ & \\
\hline$>2500$ & $98(31.7)$ & $142(46)$ & 1.00 Reference & \\
\hline \multicolumn{4}{|l|}{ NICU admission } & \multirow{3}{*}{$<0.001$} \\
\hline Yes & $72(23.3)$ & $16(5.2)$ & $7.63(4.16-13.99)$ & \\
\hline No & $82(26.5)$ & $139(45)$ & 1.00 Reference & \\
\hline \multicolumn{4}{|c|}{ Severe hyperbilirubinemia ${ }^{* * *}$} & \multirow{3}{*}{$<0.001$} \\
\hline Yes & $29(9.5)$ & $8(2.6)$ & 4.44 (1.96-10.07) & \\
\hline No & $120(39.5)$ & $147(48.4)$ & 1.00 Reference & \\
\hline \multicolumn{4}{|l|}{ Convulsion } & \multirow{3}{*}{$<0.001$} \\
\hline Yes & $30(9.7)$ & $1(0.3)$ & $37.26(5-277.06)$ & \\
\hline No & $124(40.1)$ & $154(49.8)$ & 1.00 Reference & \\
\hline \multicolumn{4}{|l|}{ Multiple ${ }^{* * * *}$} & \multirow{3}{*}{0.073} \\
\hline Yes & $9(2.9)$ & $18(5.8)$ & $0.47(0.21-1.09)$ & \\
\hline No & $145(46.9)$ & $137(44.3)$ & 1.00 Reference & \\
\hline
\end{tabular}

**Birth weight

*Small for gestational age (less than 10th percentile according to growth charts)

${ }_{* * *}$ The history of neonatal jaundice requires severe phototherapy or blood transfusion

****Being part of a multiple birth

Table 5: Multivariate analysis (logistic regression) used to examine the relationship between perinatal factors and developmental delay

\begin{tabular}{|c|c|c|}
\hline Variables & OR $(95 \%$ CI $)$ & P value \\
\hline \multicolumn{2}{|l|}{ Sex } & \multirow{3}{*}{0.025} \\
\hline Male & $1.92(1 / 09-3 / 38)$ & \\
\hline Female & 1.00 Reference & \\
\hline \multicolumn{2}{|c|}{ Maternal medical problems } & \multirow{3}{*}{0.011} \\
\hline Yes & $8.88(1.65-47.70)$ & \\
\hline No & 1.00 Reference & \\
\hline \multicolumn{2}{|c|}{ Fetal distress } & \multirow{3}{*}{0.022} \\
\hline Yes & $4.55(1.24-16.65)$ & \\
\hline No & 1.00 Reference & \\
\hline \multicolumn{2}{|c|}{ NICU admission } & \multirow{3}{*}{$<0.001$} \\
\hline Yes & $5.91(3.06-11.46)$ & \\
\hline No & 1.00 Reference & \\
\hline \multicolumn{2}{|c|}{ Severe hyperbilirubinemia } & \multirow{3}{*}{0.005} \\
\hline Yes & $3.82(1.50-9.70)$ & \\
\hline No & 1.00 Reference & \\
\hline \multicolumn{2}{|l|}{ SGA } & \multirow{3}{*}{0.012} \\
\hline Yes & $7.71(1.55-38.29)$ & \\
\hline No & 1.00 Reference & \\
\hline
\end{tabular}


as case group and 165 children aged 4-24 months with normal ASQ score as the control group were selected. Twenty-one patients, including 11 children in the case group and 10 children in the control group, were excluded due to the following: unwillingness to continue with the study and refusal to participate in the research ( 2 children), diagnosis genetic or metabolic disease ( 9 children), uncertain gestational age (5 children), and incompleteness of health records (5 children). Finally, 309 children including 154 cases in the case group and 155 in the control group were analyzed.

The results of the univariable analysis showed that among the demographic and reproductive factors, sex and number of children of the family had a significant relationship with developmental delay (Table 1). During pregnancy, the variables of maternal medical problems, drug consumption during pregnancy and the history of vaginal bleeding during the first trimester of pregnancy had a significant effect on developmental delay (Table 2). In the univariable analysis, drug consumption during pregnancy had a significant relationship with the child developmental delay. In the present study, the type and amount of drugs used and the duration of use was not investigated separately due to the small sample size.

Among the delivery information, the type of cesarean section, preterm labor and fetal distress had a significant effect on developmental delay (Table 3). The effect of all complications and problems of the neonatal period was significant on developmental delay except for multiple pregnancies (Table 4). The mean duration of hospitalization in NICU was significantly higher in the case group $(\mathrm{p}<0.001)(11.84$ vs. 2.59 days).

In order to investigate the simultaneous effect of all variables on developmental delay, the logistic backward stepwise regression model with was used. All variables that were significant in univariable analysis were included into the model. Meanwhile, due to the co-linearity of the two variables of maternal medical problems and drug use, these were not employed into the logistic regression model, concurrently. Also, in two variables, the history of neonatal

Table 6: Relationship between different developmental domains related to sex and prematurity

\begin{tabular}{|c|c|c|c|c|c|c|c|}
\hline \multirow[b]{2}{*}{ Domains } & \multicolumn{3}{|c|}{ GA(week) } & \multicolumn{3}{|c|}{ Child sex } & \multirow[b]{2}{*}{ Total N(\%) } \\
\hline & $<37 \mathrm{~N}(\%)$ & $>37 \mathrm{~N}(\%)$ & $P$ value & Male N(\%) & Female N(\%) & P value & \\
\hline \multicolumn{8}{|c|}{ Communication } \\
\hline Yes & 21 (13.6) & $66(42.9)$ & \multirow{3}{*}{0.607} & $51(33.1)$ & $36(23.4)$ & \multirow{3}{*}{0.250} & 87 (56.5) \\
\hline No & 18 (11.7) & $40(26.0)$ & & $41(26.6)$ & $17(11.0)$ & & $58(37.7)$ \\
\hline Suspicious & $3(1.9)$ & $6(3.9)$ & & $7(4.5)$ & $2(1.3)$ & & $9(5.8)$ \\
\hline \multicolumn{8}{|c|}{ Gross motor } \\
\hline Yes & $33(21.4)$ & 79 (51.3) & \multirow{3}{*}{0.208} & $68(44.2)$ & 44 (28.6) & \multirow{3}{*}{0.031} & $112(72.2)$ \\
\hline No & $7(4.5)$ & $31(20.1)$ & & $30(19.5)$ & $8(5.2)$ & & $38(24.7)$ \\
\hline Suspicious & $2(1.3)$ & $2(1.3)$ & & $1(0.6)$ & $3(1.9)$ & & $4(2.6)$ \\
\hline \multicolumn{8}{|l|}{ Fine motor } \\
\hline Yes & 27 (17.5) & 38 (24.7) & \multirow{3}{*}{0.002} & $37(24.0)$ & $28(18.2)$ & \multirow{3}{*}{0.149} & 65 (42.2) \\
\hline No & $15(9.7)$ & $70(45.5)$ & & $60(39.0)$ & $25(16.2)$ & & 85 (55.2) \\
\hline Suspicious & $0(0.0)$ & $4(2.6)$ & & $2(1.3)$ & $2(1.3)$ & & $4(2.6)$ \\
\hline \multicolumn{8}{|c|}{ Problem solving } \\
\hline Yes & $25(16.2)$ & $48(31.2)$ & \multirow{3}{*}{0.125} & $43(27.9)$ & $30(19.5)$ & \multirow{3}{*}{0.410} & $73(47.4)$ \\
\hline No & $15(9.7)$ & $60(39.0)$ & & $52(33.8)$ & $23(14.9)$ & & 75 (48.7) \\
\hline Suspicious & $2(1.3)$ & $4(2.6)$ & & $4(2.6)$ & $2(1.3)$ & & $6(3.9)$ \\
\hline \multicolumn{8}{|c|}{ Personal-social } \\
\hline Yes & 24 (15.6) & $42(27.3)$ & \multirow{3}{*}{0.064} & $39(25.3)$ & 27 (17.5) & \multirow{3}{*}{0.077} & $66(42.9)$ \\
\hline No & $18(11.7)$ & $66(42.9)$ & & $59(38.3)$ & $25(16.2)$ & & $84(54.5)$ \\
\hline Suspicious & $0(0.0)$ & $4(2.6)$ & & $1(0.6)$ & $3(1.9)$ & & $4(2.6)$ \\
\hline
\end{tabular}


seizure and history of vaginal bleeding, because of the small sample size in the control group, the accuracy of OR and CI estimates decreased, so they were eliminated from logistic regression model.

The results showed that the following factors had a significant effect on development delay after controlling the effect of confounding other factors (Table 5): being male $(\mathrm{P}=0.025)$, having maternal medical problems $(P=0.011)$, fetal distress $(P=0.022)$, the history of hospitalization in the NICU $(\mathrm{P}<0.001)$, severe neonatal jaundice $(\mathrm{P}=0.005)$, and SGA $(\mathrm{P}=$ 0/012).

The results indicated that in the case group, the highest prevalence of developmental delay was related to the area of gross motor skills, followed by communication, problem solving, personal-social and fine motor skills. The Fisher's exact test, used to examine the relationship between different developmental domains with sex, showed that the prevalence of developmental delays in gross motor domain in boys was more than in girls but there were not any differences in the prevalence of other domains between two sexes. In the study of the relationship between different developmental domains and prematurity in the case group, the results showed that there was a significant relationship between delays in fine motor area and prematurity (Table 6).

\section{DISCUSSION}

In the present study, being male had a significant relationship with developmental delay. Also, in examining the relationship between different developmental domains with sex, the prevalence of developmental delay in the gross motor area was significantly higher in boys. In Schonhaut et al.'s study, being male showed a significant and strong correlation with developmental delay (6). In the study of Mora et al., the male sex was a risk factor for the developmental delay (3). The results of Warshafsky et al.'s research showed that boys had a higher risk of developmental delay than girls based on ASQ scores (9). According to Whitehouse et al.'s study, a high level of testosterone in the male umbilical cord was a risk factor for speech developmental delay at the age of 1, 2 and 3 years old (15). Recent research suggests the effect of epigenetic mechanisms on sex differences in the human brain. The results of these studies showed that changes in gene expression caused sex differences in the brain development $(16,17)$. A study by Bale et al. showed that in the fetal period, there are differences in the placental cells of two sexes that are caused by sex chromosomes. X-linked genes that are expressed in female placental cells place the placenta in a position that is less vulnerable to the surrounding environment, and this provides a protective condition for the development of the brain (18). However, no significant correlation was found between sex and developmental delay in a study of Soleimani et al. (19). Differences in results can be due to differences in sampling and developmental evaluation criteria. For example, the evaluation criterion for development in the Soleimani et al.'s study has been the Infant Neurological International Battery Test (INFANIB), which is different from other studies.

In the present study, maternal medical problems had a significant effect on developmental delay. Medical problems such as autoimmune, cardiovascular, renal and neurological diseases were included in a variety of maternal medical problems due to the small sample size. All of these problems make a pregnancy as high risk pregnancy and can affect both the development of the fetus and the child's development (20).

In this study, the abnormal pattern of fetal heart rate during labor and fetal distress had a significant effect on developmental delay in children. In the study of de.Moura et al., the type of delivery, cesarean section or natural did not have a significant relationship with the developmental delay of children (3). In the study of Kerstjens et al., cesarean section in a univariate analysis had a significant correlation with developmental delay but has not been significantly correlated in multivariate analysis (5). In the study of Martínez-Nadal et al., cesarean delivery was associated with the risk of developmental delay, especially in the gross motor area (10). In the present study, the type of delivery (normal or cesarean section) did not have a significant relationship with developmental delay, but after separating the type of cesarean into emergency and elective in the univariate analysis, emergency cesarean showed a significant relationship with developmental delay. On the other hand, the abnormal pattern of fetal heart rate during labor had a significant relationship with the developmental delay in univariate and multivariate analysis. Therefore, according to the results of this study and other studies, it can be said that cesarean delivery is not an impor- 
tant risk factor for the development of a newborn, but a factor causing emergency cesarean section such as fetal distress during labor, which may delay the development of the children (4).

In this study, prematurity was significant in the univariate analysis, but in the logistic regression model, taking into account the effect of other factors, it was not significant. In the assessment of the relationship between different developmental domains with prematurity, the premature children were significantly more likely to have developmental delay in the fine motor area than those who were born in term. In the study of Piek et al., the gestational age at birth was associated with fine motor skill in school age (21). Fine motor skill is one of the main components of the good functioning of the hand, and visual-movement that includes school performance. Several studies have shown that premature children have poor visual-motor coordination and motor function. It has been shown that this group of children have a higher risk of poor school performance and learning difficulties $(22,23)$. In the study of Bolk et al., the brain volume of immature children was correlated with function score of visual-motor coordination and fine motor skills at 6.5 years of age (24). Therefore, early diagnosis of developmental delay in fine motor skills in children with early birth can be effective in improving the performance of these children at school.

In the present study, the history of hospitalization in the NICU, as well as the duration of hospitalization in this part, have a significant relationship with developmental delay. According to the results of Ballantyne et al., there was a higher risk of developmental delay in children with $34-41$ weeks of gestation with history of admission in the NICU (7). In the NICU, factors such as exposure to 1) neurotoxic chemicals, 2) inadequate light, 3) excessive sound, and 4) social interaction limitation affect long-term neurobehavioral outcomes in this vulnerable population (25).

Several observational studies have shown a strong association between hyperbilirubinemia and auditory system damage. This damage may occur in the absence of other classic symptoms of Kernicterus and may range from minor hearing damage and speech disorder to complete deafness. The damage to the hearing system has a huge impact on these children. For example, hearing performance has a broad relationship with speech development. Hyperbilirubinemia is one of several risk factors for the hearing loss. Other risk factors for the hearing loss in infants include a high-noise environment for the NICU, exposure to aminoglycosides, central nervous system infection, and hypoxia at birth. These risk factors are more prevalent in premature infants, and premature neonates are more likely to have bilirubin-induced neurological damage than term neonates (26). According to the results of Wusthoff et al., bilirubin-induced neurological damage may develop as a developmental and cognitive impairment or behavioral and psychological disorder after the neonatal period (27). In the present study, the history of jaundice with severe phototherapy or blood transfusion in case group was more than in the control group. This relationship has been statistically significant in a univariate and multivariate analysis, and according to the abovementioned issue, this relationship is justifiable. Therefore, the clarification of the history of jaundice in infancy can be useful in children who are at risk to developmental delay.

In the present study, SGA was significantly associated with developmental delay. This conclusion is consistent with the results of some studies. In the study of Kerstjens et al., SGA is associated with an increased risk of developmental delay (5). In the study by Mello et al., SGA children had significantly less scores in motor and behavioral evaluation at two months of age (28). Many children born with SGA have had chronic nutritional needs and oxygen during the fetal period. These chronic defects may alter the structure of the brain and development status (5).

In the case group, the most prevalent developmental delay was in gross motor area $(72.8 \%)$. In their study, Valla L et al. showed that the highest incidence of developmental delay in the first year of life was in the gross motor area (29), which is consistent with the present study. However, in the study of Amir Ali Akbari et al., the most prevalent developmental delay was in the fine motor area (30). The reason for this difference may be because of the difference in the age range of the children being studied. In the present study, children aged $4-24$ months and in the Vala's study children with $4-12$ years old were studied, while, a study by Amir Ali Akbari et al. have been conducted on children aged 4 - 60 months. Mayson et al. showed that motor development in children is one of the most important indicators of neurological health and can be used to diagnose children with developmental delay (31). Therefore, child motor development 
should be given special attention.

The strength of this study is the existence of a control group and the use of ASQ for assessing the development of children. ASQ is a valid questionnaire in many populations and even in high-risk children. There were some limitations in this study: first, because of the retrospective nature of the study, it was not possible to assess some information. Second, the study power was low to assess the association of some of the perinatal factors that had a low incidence.

\section{CONCLUSION}

The results of this study showed that being male, the existence of maternal medical problems, fetal distress, history of hospitalization in NICU, severe neonatal jaundice and SGA can predict developmental delay. By regular follow-up of children who are at risk of developmental delay due to perinatal conditions, developmental delay can be diagnosed early and necessary interventions can be performed.

\section{Conflict of interest}

The authors declare that they have no conflict of interest.

\section{References}

1. Shonkoff JP, Richter L, van der Gaag J, Bhutta ZA. An integrated scientific framework for child survival and early childhood development. Pediatrics 2012; 129: e460-72.

https://doi.org/10.1542/peds.2011-0366

2. Klienman RM, Stanton B, Geme J, Schor NF, Nelson textbook of pediatrics. 20 $0^{\text {th }}$ ed, Philadelphia, PA: Elsevier; 2015.

3. de Moura DR, Costa JC, Santos IS, et al. Risk factors for suspected developmental delay at age 2 years in a Brazilian birth cohort. Paediatr Perinat Epidemiol 2010; 24: 211-21.

https://doi.org/10.1111/j.1365-3016.2010.01115.x
4. Bear LM. Early identification of infants at risk for developmental disabilities. Pediatr Clin North Am 2004; 51: 685-701.

https://doi.org/10.1016/j.pcl.2004.01.015

5. Kerstjens JM, de Winter AF, Sollie $\mathrm{KM}$, et al. Maternal and Pregnancy-Related Factors Associated With Developmental Delay in Moderately Preterm-Born Children. Obstet Gynecol 2013; 121: 727-33. https://doi.org/10.1097/AOG.0b013e3182860c52

6. Schonhaut L, Armijo I, Pérez M. Gestational age and developmental risk in moderately and late preterm and early term infants. Pediatrics 2015; 135: e835-41. 
https://doi.org/10.1542/peds.2014-1957

7. Ballantyne M, Benzies KM, McDonald S, MagillEvans J, Tough S. Risk of developmental delay: Comparison of late preterm and full term Canadian infants at age 12 months. Early Hum Dev 2016; 101: 27-32. https://doi.org/10.1016/j.earlhumdev.2016.04.004

8. Majewska J, Zajkiewicz K, Wacław-Abdul K, Baran J, Szymczyk D. Neuromotor Development of Children Aged 6 and 7 Years Born before the 30th Week Gestation. BioMed Res Int 2018; 2018: 2820932.

https://doi.org/10.1155/2018/2820932

9. Warshafsky C, Pudwell J, Walker M, Wen SW, Smith GN. Prospective assessment of neurodevelopment in children following a pregnancy complicated by severe pre-eclampsia. BMJ Open 2016; 6: e010884.

https://doi.org/10.1136/bmjopen-2015-010884

10. Martínez-Nadal S, Demestre $\mathrm{X}$, Schonhaut L, Muñoz SR, Sala P. Impact of neonatal morbidity on the risk of developmental delay in late preterm infants. Early Hum Dev 2018; 116: 40-6.

https://doi.org/10.1016/j.earlhumdev.2017.11.001

11. Walker SP, Wachs TD, Gardner JM, Lozoff B, Wasserman GA, Pollitt E, Carter JA. Child development: risk factors for adverse outcomes in developing countries. Lancet 2007; 369: 145-57. https://doi.org/10.1016/S0140-6736(07)60076-2

12. Tsai HLA, McCleilopd MM, Pratt C, Squires J. Adaptation of the 36-Month Ages and Stages Questionnaire in Taiwan: Results from a Preliminary Study. J Early Interv 2006; 28: 213. https://doi.org/10.1177/105381510602800308

13. Kerstjens JM, Bos AF, Vergert EMJ, Meer G, Butcher PR, Reijneveld SA. Support for the global feasibility of the Ages and Stages Questionnaire as developmental screener. Early Hum Dev 2009; 85: 443-47.

https://doi.org/10.1016/j.earlhumdev.2009.03.001

14. Vameghi R, Sajedi F, Kraskian Mojembari A, Habiollahi A, Lornezhad HR, Delavar B. CrossCultural Adaptation, Validation and
Standardization of Ages and Stages Questionnaire (ASQ) in Iranian Children. Iran J Public Health 2013; 42 :522-28.

15. Whitehouse AJ, Mattes E, Maybery MT, et al. Sexspecific associations between umbilical cord blood testosterone levels and language delay in early childhood. J Child Psychol Psychiatry 2012; 53:726-34.

https://doi.org/10.1111/j.1469-7610.2011.02523.x

16. Chung WC, Auger AP. Gender differences in neurodevelopment and epigenetics. Pflugers Arch 2013; 465: 573-84.

https://doi.org/10.1007/s00424-013-1258-4

17. Turano A, Osborne BF, Schwarz JM. Sexual Differentiation and Sex Differences in Neural Development. Current Topics in Behavioral Neurosciences. Berlin: Heidelberg , Springer; 2018.

https://doi.org/10.1007/7854 201856

18. Bale TL. The placenta and neurodevelopment: sex differences in prenatal vulnerability. Dialogues Clin Neurosci 2016; 18: 459-64.

https://doi.org/10.31887/DCNS.2016.18.4/tbale

19. Soleimani F, Vameghi R, Biglarian A, Rahgozar M. Prevalence of motor developmental disorders in children in Alborz province, Iran in 2010. Iran Red Crescent Med J 2014; 16: e16711. https://doi.org/10.5812/ircmj.16711

20. Torabi F, Akbari SA, Amiri S, Soleimani F, Majd HA. Correlation between high-risk pregnancy and developmental delay in children aged 4-60 months. Libyan J Med 2012; 7:18811.

https://doi.org/10.3402/lim.v7i0.18811

21. Piek JP, Dawson L, Smith LM, Gasson N. The role of early fine and gross motor development on later motor and cognitive ability. Hum Mov Sci 2008; 27: 668-81.

https://doi.org/10.1016/j.humov.2007.11.002

22. Volman MJ, van Schendel BM, Jongmans MJ. Handwriting difficulties in primary school children: A search for underlying mechanisms. Am J Occup The 2006; 60:451-60. https://doi.org/10.5014/ajot.60.4.451 
23. Kerstjens JM, de Winter AF, Bocca-Tjeertes IF, ten Vergert EM, Reijneveld SA, Bos AF. Developmental delay in moderately preterm-born children at school entry. J Pediatr 2011; 159: 92-8. https://doi.org/10.1016/j.jpeds.2010.12.041

24. Bolk J, Padilla N, Forsman L, Broström L, Hellgren K, Åden U. Visual-motor integration and fine motor skills at $6 \frac{1}{2}$ years of age and associations with neonatal brain volumes in children born extremely preterm in Sweden: a population-based cohort study. BMJ Open 2018; 8: e020478.

https://doi.org/10.1136/bmjopen-2017-020478

25. Santos J, Pearce SE, Stroustrup A. Impact of hospital-based environmental exposures on neurodevelopmental outcomes of preterm infants. Curr Opin Pediatr 2015; 27: 254-60. https://doi.org/10.1097/MOP.0000000000000190

26. Olds C, Oghalai JS. Audiologic impairment associated with bilirubin-induced neurologic damage. Semin Fetal Neonatal Med 2015: 20: 42-6. https://doi.org/10.1016/j.siny.2014.12.006

27. Wusthoff CJ, Loe IM. Impact of bilirubin-induced neurologic dysfunction on neurodevelopmental outcomes. Semin Fetal Neonatal Med 2015 : 20: 52-7. https://doi.org/10.1016/j.siny.2014.12.003

28. Mello B, Gagliardo H, Gonçalves V. Neurodevelopment of small-for-gestational age infants: behavioral aspects in first year. Arq Neuro-Psiquiatr 2014; 72: 517-23. https://doi.org/10.1590/0004-282X20140096

29. Valla L, Wentzel-Larsen T, Hofoss D, Slinning K. Prevalence of suspected developmental delays in early infancy: results from a regional populationbased longitudinal study. BMC Pediatr 2015; 15 : 215.

https://doi.org/10.1186/s12887-015-0528-z

30. Amir Ali Akbari S, Montazeri S, Torabi F, Amiri S, Soleimani F, Majd HA. Correlation between anthropometric indices at birth and developmental delay in children aged 4-60 months in Isfahan, Iran. Int J Gen Med 2012; 5: 683-87.

https://doi.org/10.2147/IJGM.S34806

31. Mayson TA, Harris SR, Bachman CL. Gross motor development of Asian and European children on four motor assessments: a literature review. Pediatr Phys Ther 2007; 19:148-53. https://doi.org/10.1097/PEP.0b013e31804a57c1 


\title{
Odnos između problema u perinatalnom periodu i zastoja u razvoju kod dece starosti od četiri do dvadeset četiri meseca
}

\author{
Masoumeh Kaviani ${ }^{1}$, Zhaleh Ranjbaran², Roksana Janghorban ${ }^{3}$ \\ ${ }^{1}$ Departman za akušerstvo, Fakultet za sestrinstvo i akušerstvo, \\ Društveni psihijatrijski centar za istraživanja, Univerzitet medicinskih nauka u Širazu, Širaz, Iran \\ ${ }^{2}$ Student magistarsih studija akušerstva, Studentski istraživački komitet, Departman za akušerstvo, \\ Fakultet za sestrinstvo i akušerstvo, Univerzitet medicinskih nauka u Širazu, Širaz, Iran \\ ${ }^{3}$ Departman za akušerstvo, Fakultet za sestrinstvo i akušerstvo, \\ Medicinsko-istraživački centar za majku i dete, Univerzitet medicinskih nauka u Širazu, Širaz, Iran
}

\section{S A ŽETAK}

Još uvek ima malo informacija koje se tiču kliničkih karakteristika, kvaliteta života (QoL) i manometrijskih nalaza kod neselektovanih novodijagnostikovanih slučajeva ahalazije.

Opisano je pedeset šest novodijagnostikovanih slučajeva ahalazije sa propratnim simptomima, pri čemu je primenjen standardni protokol i upotrebljen detaljni instrument koji je omogućio detaljni opis problema sa gutanjem. Funkcije mišićnog zida i distalnog sfinktera (LES) su beležene primenom standardnih manometrijskih tehnologija i kanalnih katetera. Kvalitet života ovih bolesnika je opisan pomoću instrumenta - Psychological well - being index i skale za procenjivanje gastrointestinalnih simptoma.

Kod mnogih bolesnika simptomi su dugo trajali (54,5 meseci). Čekanje kod lekara je bilo čak 5,5 meseci uprkos ozbiljnim problemima sa gutanjem (Watson skor 30.5+/-1.7; m+/- SE). Pokazalo se da je kvalitet života bio značajno poremećen kada su primenjeni generički PGWB i specifični GSRS instru-menti. Ovo pogoršanje je najverovatnije bilo uzrokovano poremećajima u gutanju. U vreme postavljanja dijagnoze motorne karakteristike tela ezofagusa i distalnog sfinktera su bile ozbiljno oštećene.

Kod većine bolesnika sa ahalazijom dijagnoza se postavlja u stadijumu kada je bolest već uveli-ko oštetila motornu funkciju jednjaka i gastroezofagijalnog spoja, a kvalitet života vidno poremećen.

Ključne reči: ahalazija, simptomi, disfagija, manometrija, donji ezofagijalni sfinkter, kvalitet života, 24časovni monitoring 